ISSN 0258-7122 (Print), 2408-8293 (Online)

Bangladesh J. Agril. Res. 41(1): 1-15, March 2016

\title{
TRIPLE CEREAL SYSTEM WITH FERTILIZER AND PLANTING MANAGEMENT FOR IMPROVING PRODUCTIVITY IN COASTAL SALINE SOILS OF BANGLADESH
}

\author{
M. ATAUR RAHMAN ${ }^{1}$, M. ATIKUR RAHMAN ${ }^{2}$ \\ N. C. D. BARMA ${ }^{1}$ AND T. P. TIWARI ${ }^{3}$
}

\begin{abstract}
A field experiment was conducted on a saline environment of Shatkhira to assess the feasibility of an intensive wheat-maize-rice cropping system with crop residue used as mulch, bed planting and fertilizer management to improve productivity. Three levels of fertilizers (Recommended dose of NPKS fertilizers, recommended fertilizers plus $50 \%$ additional $\mathrm{K}$ and $\mathrm{S}$ and recommended fertilizers with $2 \mathrm{t} / \mathrm{ha}$ ash) were assigned in main plots and four combinations of soil management and mulching (Conventional flat, Conventional with straw mulching @ 3 t/ha, Bed planting, and Bed with straw mulching@ 3 t/ha) were kept in subplots with three replications. Rice straw mulch was used after wheat sowing, wheat straw mulch was applied after maize sowing. Rice was puddle transplanted without mulch. Crop varieties like BARI GOM 25, BARI Hybrid Maize 7, and BRRI Dhan 39 were used for wheat, maize and rice, respectively. Chemical analysis of soils after two years of experimentation and the response of component crops for the two cropping cycles indicated that straw mulching either on bed or flat soil was equally effective in preventing rapid development of soil salinity in the dryer periods and thereby resulted in better stand establishment contributing to higher spikes $/ \mathrm{m}^{2}$ of wheat and ears $/ \mathrm{m}^{2}$ of maize. Available nutrient contents in soil, especially $\mathrm{P}$ (Olsen), B and $\mathrm{K}$ were improved when straw much was applied in bed or flat plantings. Application of ash with recommended fertilizer was effective in improving grain yields of component crops as compared to other fertilizer treatments without ash. The highest grain yield of wheat and maize was achieved when recommended dose of fertilizers plus ash with straw mulching were applied either in bed or flat soil condition for both the years. Treatment effect was not noted on rice yield in the first year, however the residual effect of treatments and its combinations became significant in the second year. Like wheat and maize, rice yield positively increased by fertilizer+ ash and mulching. Straw mulch and ash application contributed to soil salinity mitigation, favoured crop establishment and improved the yields of component crops.
\end{abstract}

Keywords: Straw Mulch, Bed planting, Soil Salinity, Cropping System, Ash application, Soil fertility.

${ }^{1}$ Regional Wheat Research Centre, Bangladesh Agricultural Research Institute (BARI), Gazipur, ${ }^{2}$ Agriculture Research Station, BARI, Benarpota, Shatkhira, ${ }^{3}$ CIMMYTBangladesh, House No. 10/B, Road No 53, Gulsan-2, Dhaka-1212, Bangladesh. 


\section{Introduction}

Salinity is one of the major constraints affecting crop production in the coastal regions of Bangladesh. The coastal region constitutes $20 \%$ of the total area of Bangladesh, of which about $53 \%$ is affected by different degrees of salinity (Asib, 2011). Crop productivity and cropping intensity in these regions are very low, at about half of the national average (Rahman and Ahsan, 2001). The low productivity and reduced cropping intensity are associated with tidal flooding and direct inundation of saline water during the wet season (June-October) and upward or lateral movement of saline ground water during dry season (November-May). Soil salinity can cause an accumulation of sodium (Na) on the soil surface. Sodium-induced salinity reduces infiltration and hydraulic conductivity and can accelerate surface crusting. Increased amounts of calcium $(\mathrm{Ca})$ and potassium $(\mathrm{K})$ can reduce $\mathrm{Na}$-induced dispersion by improving the balance of $\mathrm{Ca}$, magnesium $(\mathrm{Mg})$ and $\mathrm{Na}$ in soil (Khan et al., 2010). Thus application of gypsum and $\mathrm{K}$ fertilizer may improve crop production by reducing the harmful effects of $\mathrm{Na}$. Keeping the lands fallow favors the build-up high soil salinity due to capillary rise and evaporation from the bare soil, even on the higher lands. The coastal lands where flooding depth ranges from $0.3-0.6 \mathrm{~m}$ are suitable for at least two crops and sometimes three crops per year, including wheat or other suitable crops in winter, but the lack of quality irrigation water is a major constraint for winter crop production (Haque, 2006). Rice and maize cultivation are expanding in Bangladesh either in double or triple-crop systems to meet food demand of increasing population and the maize demand of livestock and poultry (Timsina et al., 2010). Introduction of wheat-maize-rice cropping with appropriate management strategies could contribute to increased system productivity and also to year-round crop coverage, which may help to reduce soil salinity. Application of crop residues as mulch reduces soil evaporation (Rahman et al., 2005), and thereby reducing the capillary rise of saline ground water. Tillage breaks and reorganizes soil capillaries, while the creation of raised beds increases the distance between the water table and the soil surface. Thus freshly prepared beds might be effective in reducing the rate of salinization of the topsoil. Furthermore, surface application of rice hull ash may also suppress soil evaporation and surface soil salinization. Considering all these factors the present experiment was undertaken to address the issue of soil salinity integrating fertilizers and locally available resources viz. ash from rice husking mill and residues of previous crop.

\section{Materials and Method}

2.1 Site: A field experiment was conducted at the Agricultural Research Station, Bangladesh Agricultural Research Institute (BARI) at Benarpota, Shatkhira $\left(22^{\circ} 43^{\prime} \mathrm{N} 89^{\circ} 06^{\prime} \mathrm{E}\right)$ to evaluate the performance of wheat-maize-rice cropping 
system as affected by soil and nutrient management and mulching with crop residues or rice hull ash. The experimental field is categorized as medium high land where flooding depth ranges from 0.2-0.5 m during the peak wet season, and soil salinization develops during the dry season. The topsoil $(0-15 \mathrm{~cm})$ is slightly alkaline silty clay with low organic matter and total nitrogen $(\mathrm{N})$ content (Table 1). The topsoil is deficient in some micronutrients, especially zinc ( $\mathrm{Zn}$ ), boron (B) and copper $(\mathrm{Cu})$, but rich in phosphorus $(\mathrm{P})$, sulfur $(\mathrm{S})$ and potassium $(\mathrm{K})$. Generally, available K content decreases in saline soil with increasing $\mathrm{Na}$ content, but at the experimental site, exchangeable $\mathrm{Ca}$ and $\mathrm{K}$ contents were much higher than of $\mathrm{Na}$ and $\mathrm{Mg}$, which is favorable for plant nutrition.

Table 1. Initial chemical properties of the topsoil $(0-15 \mathrm{~cm})$ of the experimental field, sampled on $26^{\text {th }}$ November, 2011 (after rice harvest) with critical limit

\begin{tabular}{l|c|c|c|c|c|c|c|c|c|c|c|c|cc}
\hline & $\mathrm{pH}$ & OC & \multicolumn{1}{c|}{$\begin{array}{c}\text { Total } \\
\mathrm{N}\end{array}$} & \multicolumn{1}{c|}{ Available nutrients $\left(\mu \mathrm{g} \mathrm{g}^{-1}\right)$} & \multicolumn{4}{c}{$\begin{array}{c}\text { Cation exchange } \\
\text { capacity } \\
\left(\mathrm{meq} 100 \mathrm{~g}^{-1}\right)\end{array}$} \\
\hline & & $(\%)$ & $(\%)$ & $\mathrm{P}$ & $\mathrm{S}$ & $\mathrm{B}$ & $\mathrm{Zn}$ & $\mathrm{Cu}$ & $\mathrm{Fe}$ & $\mathrm{Mn}$ & $\mathrm{K}$ & $\mathrm{Ca}$ & $\mathrm{Mg}$ & $\mathrm{Na}$ \\
\hline Initial & 8.2 & 1.21 & 0.65 & 11.7 & 114 & 0.28 & 2.0 & 0.6 & 108 & 16 & 0.48 & 9.3 & 3.1 & 0.6 \\
$\begin{array}{l}\text { Critical } \\
\text { limit }\end{array}$ & - & - & - & 7 & 14 & 0.2 & 2.0 & 1.0 & 10.0 & 5.0 & 0.2 & 2.0 & 0.8 & - \\
\hline
\end{tabular}

2.2 Experimental design: The experiment comprised three fertilizer treatments, and four combinations of planting method and mulching, in a split plot design with three replicates.

Main plots: Fertilizer treatment

$\mathrm{RF}$

: Recommended fertilizer

$\mathrm{RF}+\mathrm{KS} \quad: \mathrm{RF}+50 \%$ additional potassium and sulfur fertilizer

$\mathrm{RF}+$ Ash $\quad: \mathrm{RF}+$ Rice husk ash on the soil surface at $2 \mathrm{t} / \mathrm{ha}$ (applied to wheat and maize).

Sub-plots $(5 \mathrm{~m} \times 2.4 \mathrm{~m})$ : Combinations of planting method and mulching

Flat $\quad:$ Conventional method of flat planting

Flat + Mulch : Flat + straw mulching at $3 \mathrm{t} /$ ha (rice straw in wheat, wheat straw in maize)

Bed : Conventional tillage followed by formation of raised beds prior to wheat sowing

Bed +Mulch : Bed +straw mulch as for Flat + Mulch .

The beds were formed manually with $30 \mathrm{~cm}$ wide ridges and $60 \mathrm{~cm}$ wide from central point of one furrow to another. Beds were formed once a year prior to 
wheat sowing and two rows of wheat were sown on the beds with $20 \mathrm{~cm}$ row spacing. Upon wheat harvest beds were reshaped and one row of maize was sown on the beds manually. After maize harvest, beds were destroyed by puddling for transplanted rice. Ash and straw mulch were applied after sowing to wheat and maize only.

2.3 Crop management: Wheat was the first component crop and was sown on 26 November, 2011, followed by maize sown on 19 March, 2012 and then rice was transplanted into the puddled soil on 20 July, 2012 to complete the first cropping cycle. Similarly, the second cropping cycle was completed in 2012-13, starting with wheat sowing on 3 December, 2012 and ending with rice harvest on 30 November, 2013. The wheat was sown with a row spacing of $20 \mathrm{~cm}$ at $120 \mathrm{~kg} / \mathrm{ha}$ seed rate. The maize was sown between the wheat rows by opening the soil with a hand driven furrow opener for placement of seeds and fertilizers, after which the beds were reshaped. Maize row spacing was thus $60 \mathrm{~cm}$, and with $20 \mathrm{~cm}$ plant spacing within the rows giving 8.3 plants $/ \mathrm{m}^{2}$. BARI Gom 25, BARI Hybrid Maize 7, and BRRI Dhan39 varieties were used for wheat, maize and rice, respectively. Fertilizers (urea, triple super phosphate, muriate of potash, gypsum) were applied at the recommended rates to all crops in treatment as RF. The entire dose of all fertilizers was broadcasted during final land preparation (basal application) except for urea, which was applied at two splits (basal, top-dress). For wheat, the elemental rates were $120 \mathrm{~kg} \mathrm{~N}, 30 \mathrm{~kg} \mathrm{P}, 50 \mathrm{~kg} \mathrm{~K}$ and $20 \mathrm{~kg} \mathrm{~S} \mathrm{ha}^{-1}$, respectively, with two thirds of the urea applied basally, and the rest was broadcasted at crown root initiation (CRI) stage at 21 DAS (days after sowing). The recommended fertilizer rates used for maize were $200 \mathrm{~kg} \mathrm{~N}, 50 \mathrm{~kg} \mathrm{P}, 100 \mathrm{~kg} \mathrm{~K}$ and $40 \mathrm{~kg} \mathrm{~S} \mathrm{ha}^{-1}$, and for rice $80 \mathrm{~kg} \mathrm{~N}, 25 \mathrm{~kg} \mathrm{P}, 50 \mathrm{~kg} \mathrm{~K}$ and $20 \mathrm{~kg} \mathrm{~S} \mathrm{ha}^{-1}$. For maize and rice, onethird of urea was applied at the time of land preparation, and the rest was top dressed in two equal splits at 4 and 8 weeks after transplanting of rice and at 6-7 leaf stage and flowering stage of maize. The wheat crop was irrigated at the CRI, booting and grain filling stages. To ensure good germination and stand establishment, three irrigations were given at 3 leaf, 8 leaf and flowering stages of maize in 2012, whereas only one irrigation at 7 leaf stage other than post sowing irrigation was given for maize in 2013 due to early onset of the monsoon rains. The rice crop was entirely rain-fed.

2.4 Soil monitoring: The topsoil $(0-15 \mathrm{~cm})$ was sampled prior to the start of the experiment, and samples were collected from each plot after each crop cycle (three crops). The samples were analyzed for available nutrient contents following standard procedures at the Soil Science Laboratory of BARI. Soil electrical conductivity (EC) in each plot was measured at a regular interval of about 10 days starting from the date of wheat sowing in the second year (3 December, 2012) to June 20, 2013. Soil EC was measured by inserting the electrode of a digital 
portable EC meter (Hanna Model: HI 993310) into $10 \mathrm{~cm}$ depth at three randomly selected spots in each plot.

2.5 Crop monitoring: During maturity 10 wheat plants were sampled to measure plant height, grains/spike and thousand grain weight (TGW). Similarly rice plants were sampled to determine grains/panicle and TGW. Spikes $/ \mathrm{m}^{2}$ of wheat, panicles $/ \mathrm{m}^{2}$ of rice and cobs $/ \mathrm{m}^{2}$ of maize were counted randomly selected $1.0 \mathrm{~m} \mathrm{x}$ $1.0 \mathrm{~m}$ area with four replications in each plot. In case of maize, 5 ears from randomly selected 5 plants were collected to estimate ear length, grains/ear and TGW. At maturity, the crops were harvested duly and threshed on a whole plot basis to determine grain yield. After threshing, the grain was dried and moisture content of grain was determined for conversion of grain yields to $t^{-1} a^{-1}$ at $12 \%$ moisture content for wheat and maize, and $14 \%$ moisture for rice.

2.6 Data analysis: All data were statistically analyzed using MSTAT-C software and the mean values were compared by the least significant difference (LSD) test at $5 \%$ level of significance.

\section{Results and discussion}

3.1 Yield and yield components of wheat: Grain yield and yield components of wheat responded differently to the main effect of fertilizer levels and planting methods with mulch and also by its combinations (Table 2). Plant height and thousand grain weight (TGW) were statistically similar under different fertilizer and planting methods but varied due to its interactions. Due to interactions, all the four combinations planting methods and mulch treatments resulted in similar plant height and TGW under RF+ KS and RF+ Ash. But under RF, plant height and TGW were improved in response to straw mulch application. Fertilizer levels of $\mathrm{RF}+$ Ash produced the maximum spikes $/ \mathrm{m}^{2}$ that was closely followed by $\mathrm{RF}+\mathrm{KS}$ but significantly higher than RF. Germination and stand establishment of wheat was better under RF+ Ash that resulted in higher spikes $/ \mathrm{m}^{2}$. This advantage of higher spikes $/ \mathrm{m}^{2}$ in response to ash application contributed to higher wheat yield under RF+ Ash. However, the treatments of RF+ Ash and RF+ KS produced statistically similar grain yield in both the years. The combination of mulch and bed planting assigned in sub-plots indicated that straw mulch application on flat soil resulted in higher spikes $/ \mathrm{m}^{2}$ and grains/spike as compared to flat only. Similarly Bed+ Mulch performed better result in spikes $/ \mathrm{m}^{2}$ and grains/spike than Bed only. Bed+Mulch and Flat+Mulch were statistically similar with respect to yield, which were better than respective non-mulch bed or flat planting in both the years. The result indicated that application of rice straw as mulch either in bed or in flat planting was equally effective in improving wheat yield mainly by influencing spikes $/ \mathrm{m}^{2}$ and grains/spike of wheat. Only bed planting failed to 
produce better wheat yield but the bed was comparable to flat when straw mulch was not applied. Rahman et al. (2005) reported that mulching reduced the evaporative loss and ensured soil moisture conditions favorable for germination and stand establishment of wheat and thus contributed to productive spikes $/ \mathrm{m}^{2}$. Due to interactions, the highest yield was obtained from the treatment combination of RF+ Ash in the main plots and Bed+Mulch or Flat+ Mulch in the sub plots. Under any fertilizer level, Bed+ Much and Flat+ Mulch resulted in statistically identical yield of wheat in both the years.

3.2 Yield and yield components of maize: Maize grain yield and yield components viz. ears $/ \mathrm{m}^{2}$, ear length and grains/ear were significantly influenced by fertilizer levels and planting methods with mulch and also by its interactions (Table 3). Fertilizer levels of RF+ KS and RF+ Ash resulted in statistically similar ears $/ \mathrm{m}^{2}$, ear length and grains/ear of maize those were higher than RF. Thousand grain weight was statistically similar for different fertilizer levels but the grain yield was the maximum in RF+ Ash followed by RF+ KS but higher than RF in both the years. Thus application of ash or higher dose of potassium and sulfur fertilizer was effective in improving maize yield in this experimental environment. Due to the main effect of planting method with mulch, Flat+Mulch and Bed+Mulch produced similarly higher yield which were significantly higher than other couples of treatments receiving no mulch. Also Flat+ Mulch and Bed+ Mulch resulted in statistically similar ears $/ \mathrm{m}^{2}$ and grains/ear of maize. The result indicated that mulch application either in bed or flat were equally effective in improving yield of maize by increasing number of productive ears per unit areas with higher numbers of grains per ear. The length of maize ear was significantly higher under the aforementioned couple of treatments receiving straw mulch. The treatment of crop residue retention favored stand establishment of maize by influencing the hydraulic properties of soil resulting higher number of plants per unit area (Rahman et al., 2013), thus cobs $/ \mathrm{m}^{2}$ was improved under Bed+ Mulch and Flat+ Mulch treatments. Another fact of mulching effect in controlling the rapid development in soil salinity during the dryer period at an early growth stage of maize (Fig. 2) might also be responsible for good stand establishment that ultimately might have contributed to higher cobs $/ \mathrm{m}^{2}$. Due to interactions, the maximum grain yield was recorded in response to treatment combination of $\mathrm{RF}+$ Ash $\times$ Bed + Mulch followed by RF+ KS $\times$ Flat + Mulch in 2013. In general, yield was relatively low in 2012 compared to 2013 for all treatments and treatment combinations. However, with few exceptions the crop response to treatments was very similar for both the year. The yield advantage of maize under the interaction effect was attributed to cobs $/ \mathrm{m}^{2}$ and grains/cob as other yield components was not affected by the interaction effects. 
3.3 Yield and yield components of rice: Different fertilizer levels and planting methods with mulch and its interactions resulted in similar rice yield in the first year. However, the residual effect of treatment on grain yield and yield component viz. panicles $/ \mathrm{m}^{2}$ and grains/panicle became significant in the second year (Table 3). In 2013, number of panicle $/ \mathrm{m}^{2}$, grains/panicle and grain yield was the maximum under the fertilizer level of RF+ Ash followed by RF and RF+ KS. Application of additional $\mathrm{K}$ and $\mathrm{S}$ fertilizers in rice crop including the residual effect of those fertilizers in previous component crops under the treatment RF+ KS caused luxurious vegetative growth of rice that influenced lodging after heading (Data not presented). Thus the number of filled-grains was decreased with higher number of un-filled grains/panicle caused less grain yield under RF+KS. Different combination of straw mulch and bed planting produced similar yield statistically in both the years. Also the treatments gave similar panicles $/ \mathrm{m}^{2}$, grains $/$ panicle and grain yield under the fertilizer levels of RF+ KS when considering their factor interactions. On the contrary, under RF+ Ash, Flat+ Mulch and Bed+ Mulch produced more panicles $/ \mathrm{m}^{2}$ and higher grain yield than Flat and Bed in 2013. The mulching effect was also highest yielding under RF. The result indicated that application of ash from rice husking mill had positive effect on improving rice yield and the crop residue mulching in previous crops also played a vital positive role in improving rice yield under the experimental soil conditions.

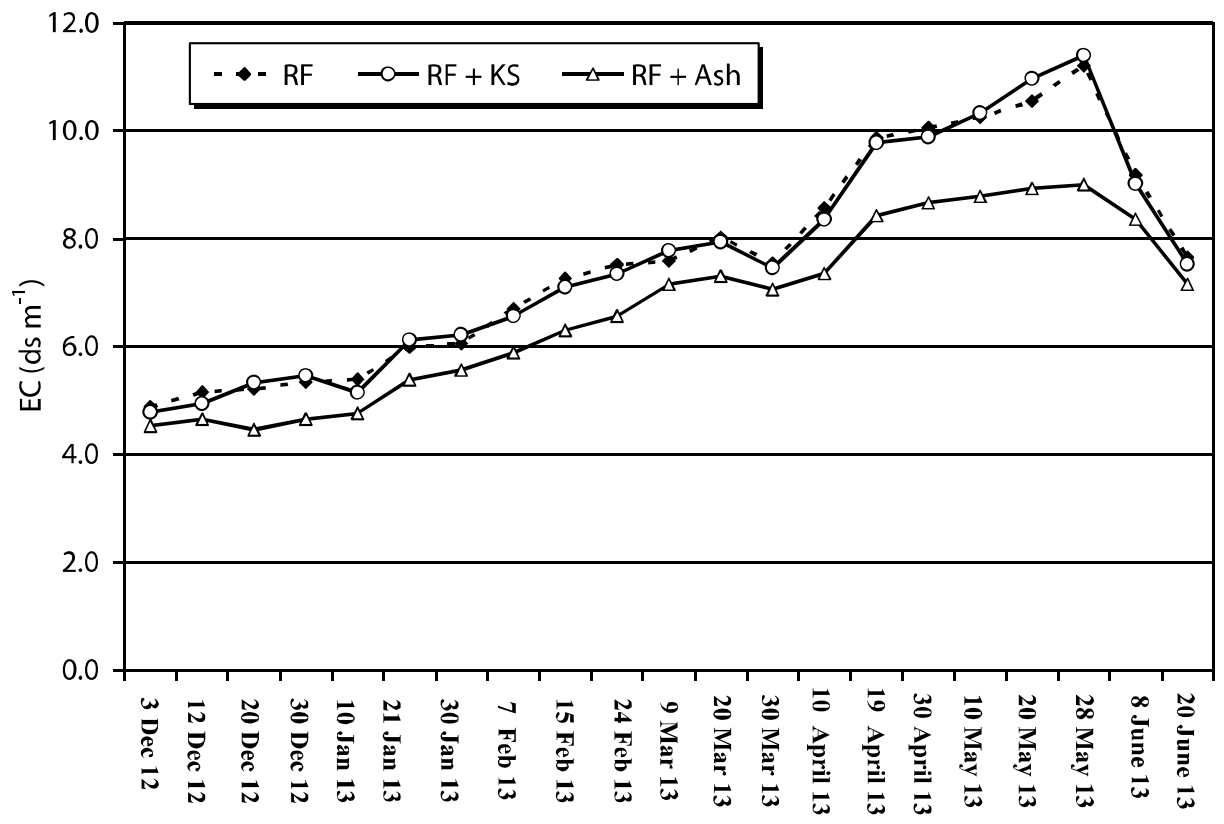

Fig. 1. Changes in soil EC with time under different fertilizer levels at Shatkhira during 2012-13. 


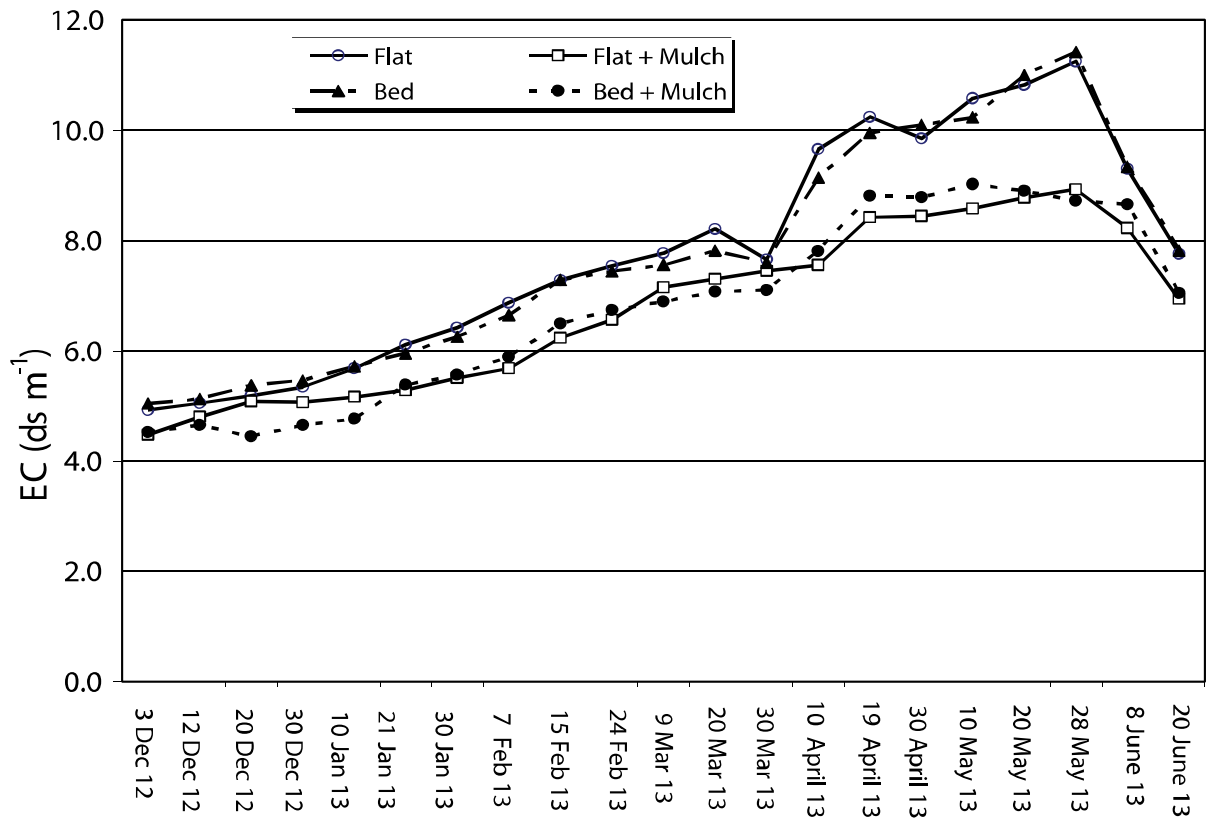

Fig. 2. Soil EC in time under planting method with mulch treatments at Shatkhira during 2012-13.
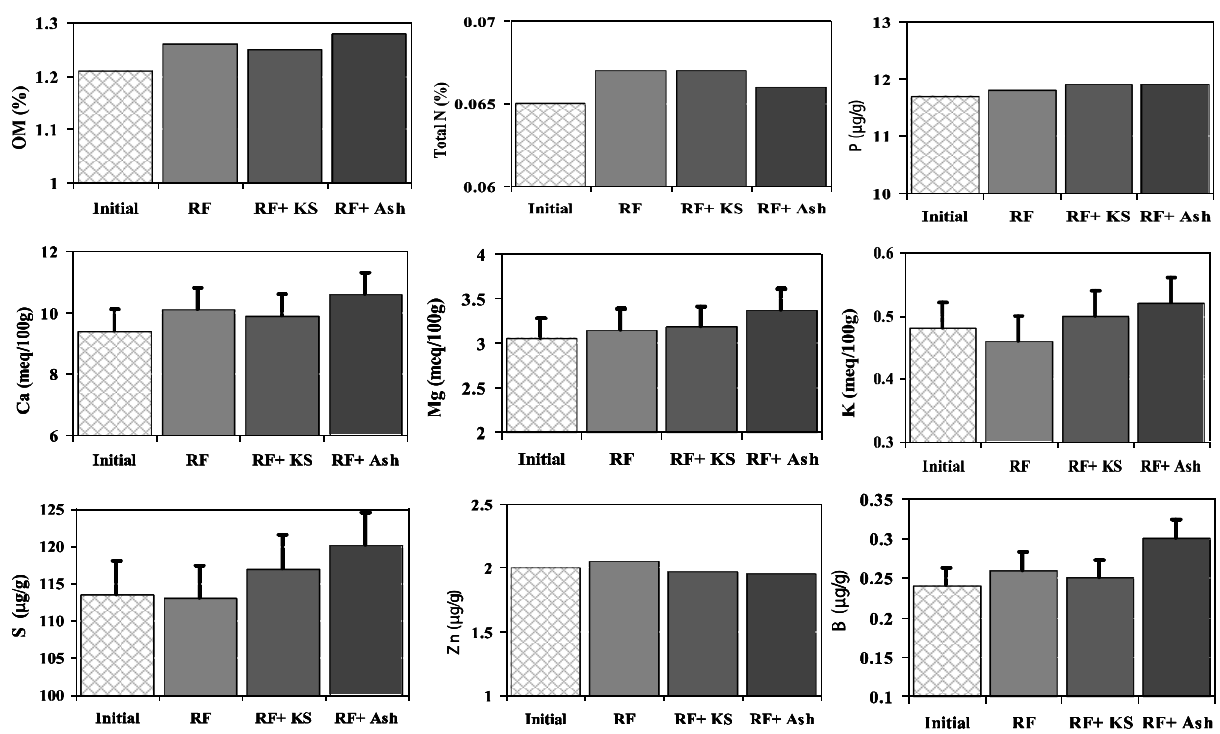

Fig. 3. Available nutrient contents in soil as affected by different fertilizer levels in relation to initial soil after two cycle of wheat-maize-rice cropping at Shatkhira (Error bar indicates LSD at $5 \%$ level of significance). 

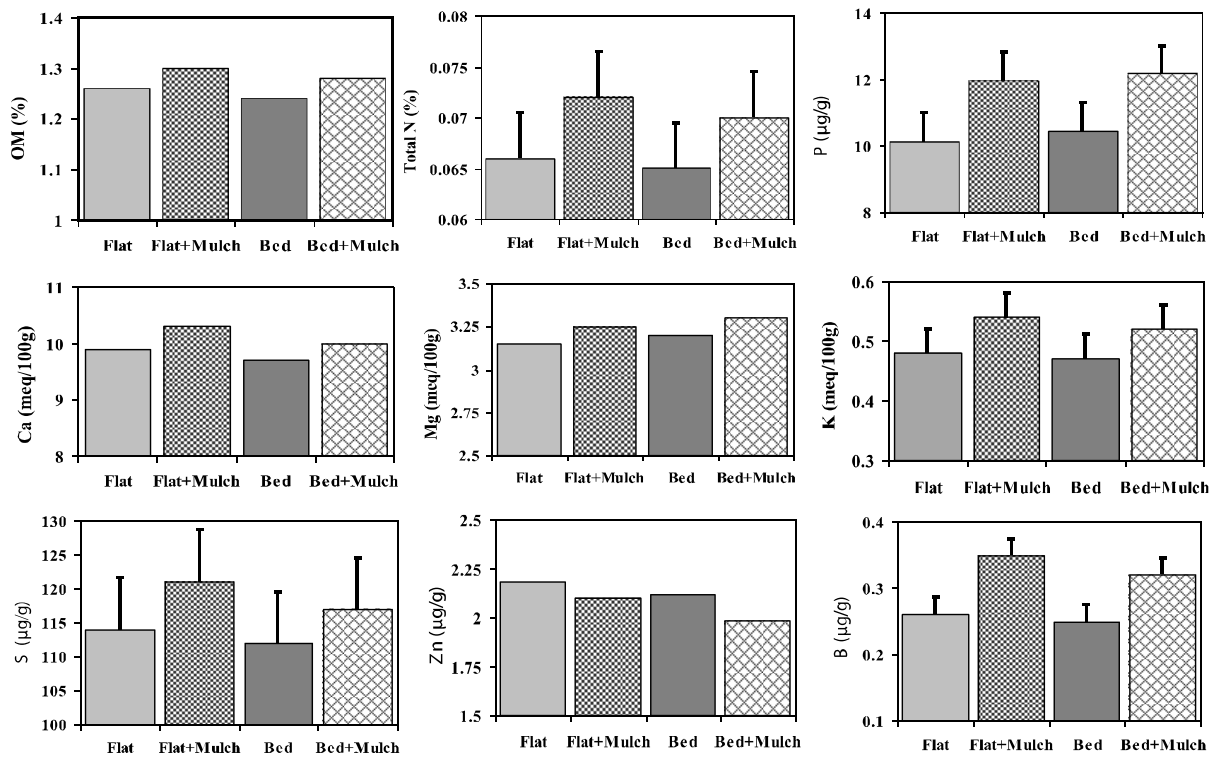

Fig. 4. Available nutrient contents in soil as affected by planting method with mulch treatments after two cycle of wheat-maize-rice cropping at Shatkhira (Error bar indicates LSD at $5 \%$ level of significance).

3.4 Soil salinity: Initially soil EC of the experimental field was around $6.7 \mathrm{ds} / \mathrm{m}$ during sowing first wheat crop on 26 November, 2011 but in the second year soil EC values came down to less than $5.0 \mathrm{ds} / \mathrm{m}$ for all the plots during sowing 2 wheat crop on 3 December, 2012. EC values were similar for different fertilizer levels and conservation treatments until the end of December (Fig. $1 \& 2$ ). Thereafter soil salinity varied in response to treatments; the soils of main plots receiving $\mathrm{RF}+$ Ash showed relatively lower EC values as compared to other fertilizer levels (Fig. 1). The variation in EC in response to treatments was wider during the dryer periods of February to May with an exception in 30 March. On 30 March, EC values dropped down for all the plots and treatment variation became narrower (Fig. 1 and 2). At that period maize seed was sown and the plots were irrigated thus EC values became closer in wet soil condition. Thereafter a rapid increasing trend was found through April and May and the treatment differences were wider. Then gradually soil EC started decreasing from early June with the on-set of monsoon rain that might have washed out the surface soils salinity. Thus the differences in EC among the plots became closer after early June, 2013. Wider variations in soil EC was observed during the peak dry periods in response to fertilizer levels and ash application was effective in preventing the rapid development of soil salinity. During drier period soil EC values largely varied in response to conservation practices (Fig. 2) and EC values were lower in plots receiving Flat+ Mulch or Bed+ Mulch treatments. Though there was no remarkable difference in EC between Bed and Flat, a declining trend was 
Table 2. Yield components and grain yield of wheat as influenced by fertilizer levels and planting methods with mulch at Benarpota, Satkhira during 2012 and 2013

\begin{tabular}{|c|c|c|c|c|c|c|}
\hline \multirow[b]{2}{*}{ Treatment } & \multicolumn{4}{|c|}{ Yield Components (2012-13) } & \multicolumn{2}{|c|}{ Grain yield $\left(\mathrm{t} \mathrm{ha}^{-1}\right)$} \\
\hline & $\begin{array}{c}\text { Plant ht. } \\
\mathrm{cm}\end{array}$ & $\begin{array}{c}\text { Spikes } \\
\mathrm{m}^{-2}\end{array}$ & $\begin{array}{l}\text { Grains } \\
\text { spike }^{-1}\end{array}$ & TGW (g) & 2013 & 2012 \\
\hline \multicolumn{7}{|l|}{ A. Fertilizer levels } \\
\hline RF & 81.4 & 271.3 & 43.7 & 47.2 & 3.33 & 3.20 \\
\hline $\mathrm{RF}+\mathrm{KS}$ & 85.2 & 317.8 & 44.8 & 49.0 & 3.62 & 3.47 \\
\hline $\mathrm{RF}+$ Ash & 88.1 & 331.6 & 45.4 & 49.4 & 3.82 & 3.65 \\
\hline $\operatorname{LSD}_{(0.05)}$ & NS & 28.6 & NS & NS & 0.35 & 0.31 \\
\hline \multicolumn{7}{|c|}{ B. Planting method with mulch } \\
\hline Flat soil & 83.1 & 276.3 & 40.1 & 47.4 & 3.23 & 3.03 \\
\hline Flat+ Mulch & 86.3 & 320.4 & 47.6 & 49.7 & 3.65 & 3.57 \\
\hline Bed & 82.2 & 303.2 & 43.5 & 47.8 & 3.47 & 3.32 \\
\hline Bed+ Mulch & 87.7 & 328.2 & 46.8 & 49.2 & 3.93 & 3.58 \\
\hline $\operatorname{LSD}_{(0.05)}$ & NS & 31.3 & 3.9 & NS & 0.39 & 0.32 \\
\hline \multicolumn{7}{|l|}{ C. Interactions } \\
\hline \multicolumn{7}{|l|}{ RF $\times$} \\
\hline Flat & 77.6 & 225.5 & 38.8 & 44.8 & 2.93 & 2.85 \\
\hline Flat+ Mulch & 82.8 & 288.8 & 45.7 & 49.1 & 3.56 & 3.32 \\
\hline Bed & 75.4 & 268.7 & 46.2 & 45.4 & 3.13 & 3.05 \\
\hline Bed+ Mulch & 84.7 & 302.3 & 45.7 & 49.4 & 3.72 & 3.68 \\
\hline \multicolumn{7}{|l|}{$\mathbf{R F}+\mathbf{K S} \times$} \\
\hline Flat soil & 82.8 & 298.5 & 41.3 & 48.8 & 3.25 & 3.05 \\
\hline Flat+ Mulch & 87.5 & 328.7 & 47.9 & 49.7 & 3.66 & 3.66 \\
\hline Bed & 84.8 & 308.5 & 42.3 & 48.9 & 3.65 & 3.32 \\
\hline Bed+ Mulch & 88.2 & 336.3 & 47.5 & 48.5 & 3.92 & 3.85 \\
\hline \multicolumn{7}{|l|}{$\mathbf{R F}+$ Ash $\times$} \\
\hline Flat soil & 88.8 & 306.0 & 42.1 & 48.7 & 3.60 & 3.22 \\
\hline Flat+ Mulch & 88.5 & 343.5 & 48.3 & 50.2 & 3.79 & 3.74 \\
\hline Bed & 86.5 & 329.7 & 43.7 & 49 & 3.64 & 3.58 \\
\hline Bed+ Mulch & 90.7 & 346.3 & 47.0 & 49.6 & 4.31 & 4.02 \\
\hline $\operatorname{LSD}_{(0.05)}$ & 8.1 & 29.8 & 4.1 & 3.9 & 0.34 & 0.33 \\
\hline $\mathrm{CV}(\%)$ & 9.2 & 7.8 & 8.1 & 7.8 & 8.6 & 9.4 \\
\hline
\end{tabular}


Table 3. Grain yield and yield components of maize as influenced by fertilizer levels and planting methods with mulch at Benarpota, Satkhira during 2012 and 2013

\begin{tabular}{|c|c|c|c|c|c|c|}
\hline \multirow[b]{2}{*}{ Treatment } & \multicolumn{4}{|c|}{ Yield Components (2012-13) } & \multicolumn{2}{|c|}{ Grain yield $\left(\mathrm{t} \mathrm{ha}^{-1}\right)$} \\
\hline & $\begin{array}{c}\text { Cobs } \\
\mathrm{m}^{-2}\end{array}$ & $\begin{array}{l}\text { Cob length } \\
(\mathrm{cm})\end{array}$ & $\begin{array}{l}\text { Grains } \\
\mathrm{Cob}^{-1}\end{array}$ & $\begin{array}{c}\text { TGW } \\
(\mathrm{g})\end{array}$ & 2012 & 2013 \\
\hline \multicolumn{7}{|l|}{ A. Fertilizer levels } \\
\hline RF & 7.07 & 17.4 & 282.0 & 232.2 & 4.84 & 4.81 \\
\hline $\mathrm{RF}+\mathrm{KS}$ & 8.28 & 19.4 & 320.6 & 234.4 & 6.22 & 5.54 \\
\hline $\mathrm{RF}+$ Ash & 8.50 & 18.8 & 316.2 & 235.7 & 6.40 & 5.62 \\
\hline $\operatorname{LSD}_{(0.05)}$ & 0.74 & 1.6 & 30.4 & Ns & 0.46 & 0.39 \\
\hline \multicolumn{7}{|c|}{ B. Planting method with mulch } \\
\hline Flat soil & 7.38 & 17.7 & 288.9 & 236.1 & 5.27 & 4.90 \\
\hline Flat+ Mulch & 9.02 & 19.1 & 313.8 & 240.0 & 7.31 & 5.70 \\
\hline Bed & 7.02 & 18.1 & 290.2 & 230.8 & 5.25 & 4.87 \\
\hline Bed+ Mulch & 8.37 & 19.2 & 331.5 & 232.3 & 7.44 & 5.67 \\
\hline $\operatorname{LSD}_{(0.05)}$ & 0.78 & 1.2 & 31.4 & Ns & 0.51 & 0.47 \\
\hline \multicolumn{7}{|l|}{ C. Interactions } \\
\hline \multicolumn{7}{|l|}{$\mathbf{R F} \times$} \\
\hline Flat & 6.76 & 16.8 & 265.5 & 234.5 & 4.21 & 4.45 \\
\hline Flat+ Mulch & 8.33 & 17.5 & 298.8 & 234.2 & 5.83 & 5.36 \\
\hline Bed & 6.05 & 17.0 & 258.8 & 226.5 & 4.05 & 4.13 \\
\hline Bed+ Mulch & 7.12 & 18.4 & 304.5 & 233.8 & 5.22 & 5.28 \\
\hline \multicolumn{7}{|l|}{$\mathbf{R F}+\mathbf{K S} \times$} \\
\hline Flat soil & 7.70 & 18.4 & 298.8 & 234.0 & 5.38 & 5.21 \\
\hline Flat+ Mulch & 9.40 & 20.2 & 324.8 & 241.2 & 7.26 & 5.83 \\
\hline Bed & 7.33 & 19.2 & 308.0 & 233.4 & 5.25 & 5.52 \\
\hline Bed+ Mulch & 8.67 & 19.8 & 349.7 & 228.8 & 6.96 & 5.86 \\
\hline \multicolumn{7}{|l|}{$\mathbf{R F}+\operatorname{Ash} \times$} \\
\hline Flat soil & 7.67 & 17.8 & 302.4 & 232.1 & 5.25 & 5.04 \\
\hline Flat+ Mulch & 9.34 & 19.5 & 317.8 & 244.5 & 7.26 & 5.87 \\
\hline Bed & 7.67 & 18.0 & 303.8 & 224.2 & 5.24 & 4.96 \\
\hline Bed+ Mulch & 9.33 & 19.5 & 340.2 & 240.2 & 7.71 & 5.98 \\
\hline $\operatorname{LSD}_{(0.05)}$ & 0.81 & 1.4 & 33.8 & NS & 0.45 & 0.34 \\
\hline $\mathrm{CV}(\%)$ & 10.3 & 7.8 & 10.5 & 11.4 & 9.1 & 10.2 \\
\hline
\end{tabular}


Table 4. Grain yield and yield components of rice as influenced by fertilizer levels and planting methods with mulch at Benarpota, Satkhira during 2012 and 2013

\begin{tabular}{|c|c|c|c|c|c|c|}
\hline \multirow[b]{2}{*}{ Treatment } & \multicolumn{4}{|c|}{ Yield Components (2013) } & \multicolumn{2}{|c|}{ Grain yield $\left(\mathrm{t} \mathrm{ha}^{-1}\right)$} \\
\hline & $\begin{array}{c}\text { Panicles } \\
\mathrm{m}^{-2}\end{array}$ & $\begin{array}{c}\text { Grains } \\
\text { panicle }^{-1}\end{array}$ & $\begin{array}{l}\text { Un-fill } \\
\text { grains } \\
\text { panicle }^{-1}\end{array}$ & $\begin{array}{c}\text { TGW } \\
(\mathrm{g})\end{array}$ & 2013 & 2012 \\
\hline \multicolumn{7}{|c|}{ A. Fertilizer levels } \\
\hline RF & 365.0 & 115.9 & 6.4 & 21.8 & 4.94 & 4.46 \\
\hline $\mathrm{RF}+\mathrm{KS}$ & 354.6 & 107.6 & 10.3 & 21.6 & 4.36 & 4.32 \\
\hline $\mathrm{RF}+$ Ash & 384.8 & 123.9 & 5.1 & 22.1 & 5.44 & 4.73 \\
\hline $\operatorname{LSD}_{(0.05)}$ & 35 & 14.2 & 1.2 & NS & 0.48 & NS \\
\hline \multicolumn{7}{|c|}{ B. Planting methods with mulch } \\
\hline Flat soil & 365.2 & 118.8 & 7.9 & 21.8 & 4.76 & 4.54 \\
\hline Flat+ Mulch & 373.6 & 113.9 & 7.6 & 21.7 & 5.15 & 4.51 \\
\hline Bed & 359.6 & 114.1 & 7.3 & 21.9 & 4.72 & 4.45 \\
\hline Bed+ Mulch & 374.0 & 116.4 & 8.1 & 22.0 & 5.14 & 4.50 \\
\hline $\operatorname{LSD}_{(0.05)}$ & NS & NS & NS & NS & NS & NS \\
\hline \multicolumn{7}{|l|}{ C. Interactions } \\
\hline \multicolumn{7}{|l|}{$\mathbf{R F} \times$} \\
\hline Flat & 352.6 & 119.4 & 6.2 & 21.3 & 4.68 & 4.45 \\
\hline Flat+ Mulch & 386.2 & 115.9 & 6.5 & 21.7 & 5.12 & 4.58 \\
\hline Bed & 344.3 & 110.4 & 6.0 & 22.1 & 4.72 & 4.48 \\
\hline Bed+ Mulch & 377.1 & 118.0 & 6.7 & 22.3 & 5.22 & 4.71 \\
\hline \multicolumn{7}{|l|}{$\mathbf{R F}+\mathbf{K S} \times$} \\
\hline Flat soil & 347.8 & 107.4 & 10.5 & 22.1 & 4.25 & 4.30 \\
\hline Flat+ Mulch & 355.1 & 107.0 & 11.0 & 21.3 & 4.47 & 4.42 \\
\hline Bed & 350.3 & 104.9 & 8.9 & 21.7 & 4.34 & 4.12 \\
\hline Bed+ Mulch & 364.1 & 111.2 & 10.8 & 21.4 & 4.52 & 4.23 \\
\hline \multicolumn{7}{|l|}{$\mathbf{R F}+\operatorname{Ash} \times$} \\
\hline Flat soil & 394.6 & 129.7 & 5.4 & 22.1 & 5.26 & 4.72 \\
\hline Flat+ Mulch & 379.5 & 118.7 & 5.1 & 22.2 & 5.85 & 4.56 \\
\hline Bed & 384.1 & 127.0 & 5.5 & 22.0 & 5.17 & 4.54 \\
\hline Bed+ Mulch & 380.8 & 120.1 & 4.6 & 22.3 & 5.68 & 4.63 \\
\hline $\operatorname{LSD}_{(0.05)}$ & 34.5 & 14.2 & 1.1 & NS & 0.43 & NS \\
\hline $\mathrm{CV}(\%)$ & 10.2 & 7.5 & 7.7 & 6.5 & 9.4 & 8.5 \\
\hline
\end{tabular}


observed in Bed with few exceptions. In few cases the EC value in Bed was higher than the Flat. Generally, salinity developed unevenly in the field and very often it was patchy in nature. Thus, EC in bed was higher than flat in some cases. Mulch applications either in bed or flat were equally effective in preventing rapid development of soil salinity compared to non-mulched treatments. Bed planting alone was unable to prevent soil salinity by breaking and reorganizing soil capillaries as expected during planning the experiment. Also the application of $50 \%$ higher $\mathrm{K}$ and $\mathrm{S}$ fertilizer was ineffective in contributing salinity management. Whereas the combination of ash application in the main plots and straw mulch application in the sub plots was effective in preventing rapid development of soil salinity. Rengasamy (2006) described soil salinization as a complex process involving the movement of salts and water in soils varying with seasonal cycles, interacting with groundwater and rainfall. Yang et. al (2006) reported that mulching was effective in conserving soil water decreasing surface soil salinity and thereby improved wheat yield. Present experiment also demonstrated the seasonal variation of salinity in coastal surface soil $(0-15 \mathrm{~cm}$ depth) and straw mulching was effective in reducing salinity during the dryer seasons. The use of crop straw as mulch in field crops is rare in Bangladesh condition. The farmers use crop straw mostly as fodder for their livestock and as fuel. Under such a competitive need for crop residues, 3.0 t/ha straw mulch application seems to be unaffordable to the marginal farmers. However, considering the direct and residual effect of mulch in salinity management and crop productivity the farmers could prefer straw mulching whenever have the alternate source of fuel and fodder.

3.4 Soil nutrient contents: The initial soil was poor in organic matter and total $\mathrm{N}$ content, but the soil was rich in $\mathrm{P}, \mathrm{K}$ and $\mathrm{S}$ contents and the soil was deficient in some of the micro-nutrients especially $\mathrm{Zn}$ and $\mathrm{B}$ (Table 1 ). Generally, available $\mathrm{K}$ content decreases in saline soil with an increase in Na content which was not found in the experimental field. The changes in nutrient availability in such a soil after two cycles of cropping indicated that available nutrient contents in soil did not decline due to intensive wheat-maize-rice cropping. Rather in some cases, availability of nutrient was improved in response to fertilizer levels and planting methods with mulch treatments (Fig. $3 \&$ 4). Recommended fertilizers with ash application@2 t/ha before wheat and maize have the positive effect on $\mathrm{Ca}, \mathrm{Mg}$ and $\mathrm{S}$ contents in soil (Fig. 3). OM, P and $\mathrm{Zn}$ contents remained unchanged but $\mathrm{B}$ content was slightly declined under RF+ Ash. Planting methods with mulch treatments had the variable effect on the availability of various plant nutrients in soil (Fig. 4). Available P content in surface soil was higher in Flat+Mulch and Bed+Mulch. Similarly total N, S and B contents were relatively higher when straw mulch was applied either in flat or bed. A total of $12 \mathrm{t} / \mathrm{ha}$ straw mulch was applied in Flat+ Mulch and Bed+ Mulch treatments and during rice, those mulches were incorporated into the soil that could contribute to $\mathrm{N}, \mathrm{P}$ and $\mathrm{K}$ contents in surface soil. Also helped in reducing soil $\mathrm{pH}$ from 8.2 (during initial) to 7.9 (during second 
rice harvest), which might have also contributed to higher $\mathrm{P}$ availability in soil. The causes of higher $\mathrm{B}$ contents in response to straw much treatment was unclear. Usually the mobility of B is very high in soil-water system; coverage of soil surface with crop straw mulch may act as a barrier of loses that might have resulted in higher value of B compared to respective non-mulch treatments.

\section{Conclusions and recommendations}

The response of component crops in the system for two years cycles plus changes in soil EC in time indicated that straw mulch application is effective in improving wheat and maize yield under saline conditions on silty-clay soils. Ash from the rice husking mill also have similar positive role in improving yield of all the component crops in wheat-maize-rice system. The best result was achieved when ash was used with mulch. Bed planting alone is ineffective in contributing higher yield or controlling soil salinity. Soil nutrient contents remained either unchanged or even improved (for some elements) under the intensive triple cereal system with recommended fertilizer and straw mulches and or ash application for two year. Ash is locally available from rice husking mill, the rural household also produce some ash during cooking. Very often this ash remains unproductive and dumped on roadside with other refuses causing environmental pollution. This ash material and crop residue could be used as mulch material to improve soil health thereby improving crop productivity under saline soil condition.

\section{Acknowledgement}

We cordially acknowledge the partial financial support from CIMMYT-CSISA project at the beginning of this field experimentation that encouraged us to initiate this study.

\section{References}

Asib A., 2011. Some of the major environmental problems relating to land use changes in the coastal areas of Bangladesh: A review. Geography and Regional Planning. 4: 1-8.

Haque, S. A. 2006. Salinity problems and crop production in coastal regions of Bangladesh. Pak. J. Bot. 38: 1359-1365.

Khan, M. J., M. T. Jan, A. U. Khan, M. Arif, and M. Shafi. 2010. Management of saline sodic soils through cultural practices and gypsum. Pak. J. Bot. 42: 4143-4155.

Rahman, M. A., J. Chikushi, M. Saifuzzaman, and J. G. Lauren. 2005. Rice straw mulching and nitrogen response of no-till wheat following rice in Bangladesh. Field Crops Res. 91: 71-81.

Rahman, M. A., N. C. D. Barma, M. J. Uddin and T. P. Tiwari. 2013. Productivity of wheatmaize-rice cropping system shifted from conventional to conservation agricultural practices. In: Sustainable intensification of agriculture: Systems research helping to meet the needs and managing the trade-offs of changing world, Proceedings of the 4th 
International Symposium for Farming Systems Design. 19-22 August 2013, Lanzhou, China. Pp. 145-147.

Rahman, M. M. and M. Ahsan. 2001. Salinity constraints and agricultural productivity in coastal saline area of Bangladesh, Soil Resources in Bangladesh: Assessment and Utilization.

Rengasamy, P. 2006. World salinization with emphasis on Australia. Exp. Bot. 57: 10171023.

Timsina, J, L. M. Jat and K. Majumdar. 2010. Rice-maize systems of South Asia: current status, future prospects and research priorities for nutrient management. Springer Science+Business Media B.V. Plant Soil. 335: 65-82.

Yang, Yan-min, X. J. Liu, W.G. Li and C.Z. Li. 2006. Effect of different mulch materials on winter wheat production in desalinized soil in Heilonggang region of North China. J. Zhejiang Univ. Sci. B. 7: 858-867. 